\title{
Changing in the Aspect of Nature and Name (Istihalah): Its Point of View in the Islamic Law
}

\author{
${ }^{1}$ Abdul Basir Bin Mohamad, ${ }^{2}$ Nik Marzuki Bin Sidik, ${ }^{1}$ Anwar Fakhri Bin Omar, \\ ${ }^{1}$ Mohd Izhar Ariff Bin Mohd Kashim and ${ }^{1}$ Amir Husin Mohd Nor \\ ${ }^{1}$ Department of Syariah, Faculty of Islamic Studies, \\ ${ }^{2}$ Centre for Studies of Bioscience and Biotechnology, \\ Faculty of Science and Technology, Universiti Kebangsaan Malaysia, \\ 43600 Bangi, Selangor, Malaysia
}

\begin{abstract}
Determination of legal rulings in Islam on food that has been modified DNA is very difficult. This is because the Muslim jurists themselves have different opinions in their legal decisions to determine the foods that have been modified DNA by modern processes or well-known as istihalah in Islamic legal system. Therefore, it seems that the Muslim contemporary jurists always do an effort to solve the problem of food based on evidence taken from the Quran and the Traditions of the Prophet. Thus, the objective of this study is to identify the istihalah process that is of a major importance factor in transforming DNA of food, changing the unclean substance to the new products that benefit consumers. In addition, this study also seeks to examine all views of Muslim jurists in determining the legal ruling of istihalah. In addition, the study also provides a mechanism for the determination of the legal ruling in Islamic law, especially in the case of istihalah that produces a good product for publics. This study uses qualitative methods through instruments of data collection and content analysis based on comparative method. The findings of this study indicate that all products will be evaluated based on the final products. If the final product does not have any unclean substance, the law permits to consume it. Otherwise, it is unlawful.
\end{abstract}

Key words: Istihalah, DNA, food, legal ruling, product, biotechnology, genetic

\section{INTRODUCTION}

The term of istihalah from the point of language is derived from the root word of Arabic hala that gives meaning changing from one state to another conditions such as the change from vertical to the diagonal. Among the significations of istihalah is also a change from one character to another character that very different from its original form and characteristic.

Whereas from the point of the terminology, istihalah means to change totally a fact to another fact until it is no longer the same as its original or early characteristic. The jurists of the Maliki School of Law opine that istihalah is to change something from a form or nature to other form or nature that subsequently causes it can not be called by the name of its first form or nature.

The researchers of science are of the opinions that the word refers to the process of changing scientifically whether naturally or by chemical processes and the like. For example, the processes of oil, animal fats or plants until the original form changes to the other forms or products such as soap, butter and the like. At this time, it is no longer named with the same name in which the oil or fat but it was changed with a new name according to the end products. Thus, the process that occurs is known as istihalah.

\section{THE PROCESS OF ISTIHALAH IN BIOTECHNOLOGY}

Technology allows all kinds of changes (istihalah) committed against an organism at the molecular level. Legal uncertainty arises when these changes happen to the organism used as food or products. In terms of biotechnology, the animals that changed the DNA content are called transgenic animals or genetically modified animals (Genetically Modified Organisms, GMOs) (Tolin and Vidaver, 2009). In most cases, these changes occur at the molecular level and can not be observed in the physical organism.

For example, rice plants genetically engineered by inserting genes of cytochrome $\mathrm{P} 450$ from pig

Corresponding Author: Abdul Basir Bin Mohamad, Department of Syariah, Faculty of Islamic Studies, Universiti Kebangsaan Malaysia, 43600 Bangi, Selangor, Malaysia 
(http://www.agnet.org/library/rh/2002009b/). The purpose of the changes made are for the benefit of human beings. It seeks to make the rice plants resistant to herbicides that help farmers in farm management.

Halal animals or lawful animals in terms of the Islamic law are often genetically modified. There are two categories of halal animal products. First, genetically altered animals by inserting genes from animals that are also halal to be consumed but the gene is taken in a living animal. For example, transgenic fish carrying the gene of chicken (Ozato et al., 1986) and transgenic sheep carrying the gene that also from sheep. Second, genetically modified animals with genes from animal sources that are not halal to eat like transgenic sheep carrying gene of mice (Wall et al., 1995) transgenic fish carrying the gene of butterflies (Dunham, 2009) and transgenic rabbits carrying mice genes (Weidle et al., 1991). Meanwhile, rice (paddy tree) has been reported that it was genetically modified by using genes from insects (Giri and Laxmi, 2000).

Human genes are often expressed in transgenic animals. Cloning the genes that produce human proteins is essential for the production of proteins on a large scale for medicinal purposes. For example, human growth hormone was cloned into the transgenic rabbit (Limonta et al., 1995), lisozim human protein expressed in sheep so as to the sheep can produce human lisozim in its milk (Maga et al., 2006) and the production of proteins of human $\alpha$-laktalbumin in milk of transgenic cows (Wang et al., 2008). However, the rush to produce human proteins in animals, the animals which are clearly haram or probihited for consuming in Islam are also used like the production of human proteins in transgenic pigs (Park et al., 2006). According to the basis of Islamic law, the use of pig in whatever way is clearly illegal and prohibited although, the lawful source of DNA to be put into its genetic material.

It should be noted that the genes used to produce transgenic animals or plants are not the original molecules from the original gene donor animals for instance pigs. Isolation process through several stages including a series of Polymerase Chain Reaction (PCR) and cloning action into bacteria. While running through these two stages, the original DNA of the pigs (for example) have doubled or replicated by so much that a million times which have finally caused the nature of the inserted DNA or gene into the target organism is no longer natural or original (Sambrook et al., 1989). However, it should be noted that although, the synthetic genes which are used have been instead of the original pig DNA but the features, characteristics or genes and molecular substances (proteins) produced by such genes are still the same as the original substance from pigs. Therefore, to make a judgment in terms of Islamic point of view as to food products produced by modern processes such as the above process of production needs to be refined and described in detail at all. This is intended, to avoid errors in the determination of legal judgment in the current issues.

\section{FILTH THAT HAS STRUCTURALLY BEEN CHANGED}

The Muslim jurists differ on opinion in relation to istihalah which had happened to the stool or dirt until it is changed to no stools or dirts. Change was done either through a natural process or processes of modern biotechnology. As a result of these processes, it is considered unclean in the first place are no longer seen as a stool at the end. For this reason, the Muslim jurists have a different opinions of each other with regard to the determination of legal judgment for stool or dirt that has changed its nature of stool, structure and so on to something that is no longer considered unclean by the people at the end of the processing. For example, lard which has involved a few stages of process until its substance and nature has changed to become the scented soap. So, therefore the opinions of Muslim jurists, in discussing this matter can be divided into two groups.

Group A: All kinds of shit which have changed their structures to the other ingredients are considered pure and clean without having seen the original substance. For example, lard which has been processed into soap or capsules, fat pigs which are mixed up with foods, vegetables and so on. This view is held by the Hanafi School of Law including Muhammad Bin Al-Hasan AlShaybani, the majority opinion of Maliki jurists and some views of jurists of the Hanbali School including Ibn Taymiyyah.

Hanafi jurists explained, anything that has changed its original character to another character that is entirely different with the original character, the determination of the legal judgment will be subject to its last resort. This means that all kinds of shit which have changed to something else until there is no impression of dirtiness or excrement like smell, color and flavor in new products, it is regarded as clean and lawful to be consumed by Muslims without hesitation and doubt. The same judgment can also be applied to the fat pig that has been deposited in a salt manufacturing materials then it is processed with other ingredients until producing the 
desired product of pure white salt that did not reflect it is a fat pig then the consumption of it is halal. Muhammad Bin Al-Hasan Al-Shaybani added that if the manure or excrement is processed either through combustion, absorption and so on until the original structure is changed to the dust, fertiliser, perfume and the like is deemed as pure and clean whether for purposes of worship or otherwise (Ibn Abidin, 1966). In relation to the issues of stool that have been modified structurally to something new, the Hanafi jurists have issued many fatwas on the matter. Among them are:

- Cooking animal flesh with its blood if it had been cooked until no blood stains on the food, it is considered pure and halal food

- Cooking tools or water pots which are made of soil with stool or of dirty clay any food which is cooked inside such pots is calculated as pure and clean. This is because the determination of the legal judgment is seen at the end of the product and not on the cooking tools or whatever equipment that used in preparing food

- Bread containing alcohol is not considered unclean if when bread was cooked it does not leave any trace of alcohol such as smell, taste and color of wine, most importantly, non-intoxicating when eaten

- Stools or dirts that are turned into either detergents or soaps are considered pure and clean

The Maliki jurists explained that each of shit has happened to change to a good thing, it is considered clean and pure. However if the opposite happens then the ruling is illegal. For example, food in the stomach is considered unclean when it comes out through the anus or mouth (vomiting) which was originally the food we eat is pure and clean. This is due to the effects of processes that occur on the food and drink into the stomach that have produced the final product-dirty and soiled with stool. Thus, the Islamic legal ruling is subject to the final product while the original material to the product can not be taken into account (Dardir, n.d.). The argument that a backup of their statements is based on equal analogy (qiyas musawah). Wine in the first place was unclean and impure according to Islamic law but it turned into pure when the istihalah process occurring until it turns into the nature of vinegar. Therefore, the determination of the legal rulings is based on and taken into account in the final product if it is good then the legal judgment is lawful if the reverse happens then the ruling is unclean and forbidden.

The same stance is supported by the jurists of Zahiri School of Law. They have asserted if a material soiled with stool that has changed its structure, nature of either color, smell and taste to the other material or other form then the ruling is also changing that is from unlawful to lawful. However, all is subject to the validity of cause/reason (illah) that found on the matter which is being dealt with legal status. If there is no cause/reason that could cause such material to be illegal and forbidden according to Islamic law and its ruling in Islam is pure and clean. Whereas if the unlawful and forbidden cause/reason is very clear and obvious then unlawful is dominant in this case. This is based on a jurisprudence legal maxim: every existing cause (illah) which being permanent and obvious is recognized as a benchmark to set a legal rule. In addition, it is also explained by another legal maxim: no doubt the change of the legal rule when the transition of time and place. However, this theory does not apply to all legislation. This is because there are some actions that Islamic law will not change even through the opinions of Muslim scholars. Among the fundamental laws of the particular set of religious texts that status through determined command of God and His beloved Prophet about the frequency and number of prayers, duty of fasting Ramadan, performing pilgrimage Hajj for a capable person, the total value of zakat payment, fixed punishment of hudud and so on.

All of the above according to the Zahiri School of Law, it seemed to draw up a legal determination of guidelines for stool that has changed the nature of the original to something else. It is a must for a legal ruling should be viewed from various angles, particularly from the aspect of cause/reason (illah) which is regarded as a main causer to a legal determination of whether it is lawful or unlawful. For this reason, this school of law holds that it is not fair to decide a new product created or produced through the faeces or excrement as impurity and unclean if the faecal matter has changed its nature to something that is no longer considered unclean.

Following this, Ibn Taymiyyah did not miss to give a full support of the views being argued by the Hanafi and Maliki jurists. He makes critically comparisons that if wine was allowed by Islam after it turns into vinegar, naturally fermented, it is more lawful if it is changed through the processes undertaken by the hands of people until it changes to something that is no longer termed as wine or alcoholic drinks. For this reason, he firmly believes that everything that would like to be banned, it should firstly be referred to the authoritative texts of the Quran or Traditions of the Prophet (the Sunnah). But if it is not available in these texts, it is the duty of the Muslim jurists to look into the illah. This is because by that way it might be helpful to the designation of the legal rule through the correct analogy (qiyas) without causing us to ban something that is allowed by God. To be noted that God 
Allah Almighty clearly justifies that every single thing on this earth except carcasses, pork, slaughtering not because of God and the blood flow as God Allah says in al-An'am, verse 145 which means:

Say (O Muhammad): I find not in the Message received by me by inspiration any (meat) forbidden to be eaten by one who wishes to eat it unless it be dead meat or blood poured forth or the flesh of swine for it is an abomination or what is impious (meat) on which a name has been invoked other than Allah's but (even so) if a person is forced by necessity without wilful disobedience nor transgressing due limits Thy Lord is Oft-forgiving, Most Merciful

The text is quoted from Surah Al-An'am is generally make it clear that Islam does not prohibit all things on this earth for the benefit of Muslims whether on purpose food, beverage, consumer, medicine, etc. unless four substances, namely animal carcasses, blood, pork and all animals slaughtered not because of God Allah. Other than as mentioned in the above verse, it is lawful to be used by Muslims as long as it is not a kind of visible stools or disgusting dirts and at the same time, it is not detrimental substances to human beings in all circumstances. This can be proved by two legal maxims held by majority Muslim jurists, namely the origin of everything is permissible until there is evidence pointing to the ban and the origin of material is pure until there is evidence showing to the impure.

Therefore, it is a great offense to the Muslims if they ban or prohibit a lawful matter in Islam without proving any evidence, argument and strong reason. This can be seen in the following verse in al-A'raf, verses 32-33 which mean:

Say: who hath forbidden the beautiful (gifts) of Allah which $\mathrm{He}$ hath produced for His servants and the things, clean and pure (which He hath provided) for sustenance? say: They are in the life of This world, for those who believe (and) purely for them on the Day of Judgment. Thus do we explain the signs in detail for those who understand. Say: the things that My Lord hath indeed forbidden are: shameful deeds whether open or secret; sins and trespasses against truth or reason; assigning of partners to Allah, for which $\mathrm{He}$ hath given no authority and saying things about Allah of which ye have no knowledge

Ibn 'Abbas narrated that this verse is revealed on to the Quraysh infidels who do tawaf (circulation) in the situation of without dresses in front of the Ka'bah and at the same time during the hajj pilgrimage they will not even eat anything, includes some fatty food. The above verse firmly explained that God vehemently denied the attitude shown by the pagan Quraysh while doing the pilgrimage in Mecca by banning themselves from eating something that God did not forbid it. This is because Allah Almighty has created a variety of food and beverages for His creature-called man. For this reason, they are liable to think how such goods can be used and enjoyed for various purposes such as food, drink, medicine and the like.

In addition, this verse also proves that Islam has thoroughly clarified the concepts of clean and unclean or lawful and unlawful in life as a whole while the matters that are not mentioned in the Quran or the Sunnah and there is no legal rulings about it, it shall be the duty of the people, especially Muslims to study and investigate such matters in accordance with the Quran, the Sunnah as well as the customary practices in particular society so that they meet the public interest for Muslims wherever they are. Hence, God Allah Almighty says in Al-Baqarah, Verse 29 which means It is He who hath created for you all things that are on earth.

If everything on this earth is to be used by human beings then why should the human beings ban it without doing any research and study at first? Because of that all the materials of animal origin, plants, water and stone, etc. which are used for the purpose of food, beverages, medical and consumerism must be made a deep and careful study in the aspect of legal rulings so that Muslims were not labelled and included in classes of banning and prohibiting something lawful by God to mankind on this earth (Naji, n.d.). Allah says in the verse of 157 of Al-A'raf which means:

He allows them as lawful what is good (and pure) and prohibits them from what is bad (and impure)

This text clearly demands Muslims to use halal ingredients for their survival whether the substance is food, beverages, medicines and so on. This verse also bans and prohibits all types of food, beverages, daily use items, etc. which are dirty and unclean. Therefore, Ibn Abbas described bad or impure in the above verse as pork, wine, liquors and all things that are prohibited by Islam is clearly determined either from animal or nonanimal.

Group B: The jurists of the Shafi 'i School of Law, among them are Shirazi (n.d.), Sharbini (n.d.) and some Hanafi jurists like Abu Yusuf (Ibn al-Humam, 2003) opine that all 
types of stools and faeces which have changed their structures to other things are still considered illegal and unlawful for consuming by Muslims even though they have naturally changed their original nature and feature into new product. For example, the ash resulting from combustion of faeces if it falls into a well in large quantities then the water will still be considered unclean. The same decision is also applied to the salt if there are dead animals in salty water which has been used for processing salt. This view was supported by Mardawi and selected approach of Ibn Qudamah of the Hanbali School of Law. Their arguments are of the Traditions of the Prophet which forbade his companions to take wine as an ingredient in food even after it has been converted into vinegar. The evidences are as follows:

Meaning: From Anas ibn Malik, the Prophet was asked whether liquor can be vinegar? So he replied, no

The above tradition shows that the Prophet forbade his companions to take liquor as an ingredient for the processing of vinegar. This is because the process of fermentation has been carried out with the hands of man. Thus, the ban on alcoholic drink or wine remains intact in any event even though its original nature and feature is already gone. The same stand is held on any illegal substances such as pork, blood and the like (Ibn Abi Ya'la, n.d.). Those are regarded as illegal and unlawful to be used by the Muslims even though the original structures have been changed to other substances, for example, fat pig that turned into pills, snacks and the like. Another legality of this group is the Tradition of the Prophet:

Meaning: From Anas ibn Malik that Abu Talhah once asked the Prophet about the orphans who had inherited some wine. Then, he (the Prophet) said, burn it. He asked again, cannot I turn it to vinegar? He said can not be

However, this argument is disputed and disagreed by jurists who justify istihalah processes that occur in the daily products of Muslims. They noted that the above traditions did not mean what is described by those who forbid the process but is meant by the traditions are replacing the vinegar with wine as a mixture ingredient in food and the like.

So with this explanation, it would not be a ban on Muslims to convert liquor to vinegar in various ways that they know and then after the process of fermentation, the outcome of it can be used as an ingredient in food and so on. This is because the outcome in this stage is no longer called as wine or liquor but it has changed its nature into another material which is known as vinegar. Strong views in this discussion is the first view of those who justify the process of istihalah in food products compared to the second view. This is because based on the strength of the evidence and arguments put forward by this group. In addition, general approach based on the public interest also taken into account in the determination of this legal rulings as a measure to protect the needs, desires and lives of Muslims in many cases, particularly in relation to the products of their daily use.

\section{CONCLUSION}

In this study, researchers can conclude that the Muslim jurists have a different opinions among them as to the issue of istihalah of stools to food products and the like. The Shafi' $i$ and Hanbali Schools of Law have emphasized that each product may be determined of its legal ruling since the early stages of processing. If it arises from a lawful material then the end product is lawful. If it is unclean and forbidden material then the end product is illegal even if its nature of unclean and impure has already changed to purity and cleanliness. While another group of the Hanafi and Maliki jurists have argued that each stool will no longer be soiled with stool when its original nature has changed to the new matter that is no longer considered unclean in the eyes of people either through taste, smell and color. View of this second group has also been supported by many famous classical and modern jurists including Ibn Taymiyyah, al-Qaradawi, Sulayman Al-Ashqar, Ibn Qayyim al-Jawziyyah and many others. However, both groups are essentially unanimous in banning all new products that can cause harm and injury to human beings either directly or otherwise. Since, the Hanafi and Maliki views preferred to be selected in this approach, a few products resulting from the stool may be looked into. Among them are as follows:

- If manure or dead animals either their origins of living is on land or in water that have been heated up to turn into ashes, the ashes are regarded as pure and clean for Muslims for daily usage, like for manufacturing of crockery, pots and so on

- Livestock is halal for food even though it has been fed with impure feeds because impure feed DNA is considered not completely mixed with the DNA of animals that have eaten such impure feed

- Stools or impure substances that have changed of their original nature to something else which is considered clean and good in the eyes of men is reckoned as clean and pure 
- All types of products that come from clean and pure, then eating of them is permissible. If the origin of a product comes from unlawful source and its essence is still existing in food product then the legal ruling of it for consuming is considered unlawful

- Food product that has been modified of its DNA, it is lawful if it is not harmful for body

- Food product that has been modified of its DNA through the DNA of animals that prohibited for consuming, it needs to be studied thoroughly its substance. If such DNA is present in food products then it is unlawful to eat and otherwise it is permissible to eat it

\section{ACKNOWLEDGEMENT}

Part of this study is an outcome of research which was conducted by using the research funding of the UKM-PP-05-FRGS0069-2009 project.

\section{REFERENCES}

Dunham, R.A., 2009. Transgenic fish resistant to infectious diseases, their risk and prevention of escape into the environment and future candidate genes for disease transgene manipulation. Compar. Immunol., Microbiol. Infectious Dis., 32: 139-161.

Giri, C.C. and G.V. Laxmi, 2000. Production of transgenic rice with agronomically useful genes: An assessment. Biol. Adv., 18: 653-683.

Limonta, J.M., F.O. Castro, R. Martinez, P. Puentes and B. Ramos et al., 1995. Transgenic rabbits as bioreactors for the production of human growth hormone. J. Biotechnol., 40: 49-58.
Maga, E.A., C.F. Shoemaker, J.D. Rowe, R.H. BonDurant, G.B. Anderson and J.D. Murray, 2006. Production and processing of milk from transgenic goats expressing human lysozyme in the mammary gland. J. Dairy Sci., 89: 518-524.

Ozato, K., H. Kondoh, H. Inohara, T. Iwamatsu, Y. Wakamatsu and T.S. Okada, 1986. Production of transgenic fish: introduction and expression of chicken $\delta$-crystallin gene in medaka embryos. Cell Differ., 19: 237-244.

Park, J.K., Y.K. Lee, P. Lee, H.J. Chung and S. Kim et al., 2006. Recombinant human erythropoietin produced in milk of transgenic pigs. J. Biotechnol., 122: 362-371.

Sambrook, J., E.F. Fritsch and T.A. Maniatis, 1989. Molecular Cloning: A Laboratory Manual. 1st Edn., Cold Spring Harbor Laboratory Press, Cold Spring Harbor, New York.

Tolin, S.A. and A.K. Vidaver, 2009. Genetically Modified Organisms: Guidelines and Regulations for Research. In: Encyclopedia of Microbiology, Schaechter, M. (Ed.). Academic Press, London, ISBN: 978-0123739391, pp: 565-577.

Wall, R.J., C.E. Jr. Rexroad, A. Powell, A. Shamay, R. McKnight and L. Hennighausen, 1995. Mouse whey acidic protein gene is expressed ectopically in transgenic sheep. Theriogenology, 43: 346-346.

Wang, J., P. Yang, B. Tang, X. Sun and R. Zhang et al., 2008. Expression and characterization of bioactive recombinant human-lactalbumin in the milk of transgenic cloned cows. J. Dairy Sci., 91: 4466-4476.

Weidle, U.H., H. Lenz and G. Brem, 1991. Genes encoding a mouse monoclonal antibody are expressed in transgenic mice, rabbits and pigs. Gene, 98: 185-191. 